\title{
Seismic Activity as a Result of Mining the Tabular and Massive Orebodies of South Deep Gold Mine
}

\author{
W.C. Joughin SRK Consulting, South Africa \\ S.Z. Pethö Placer Dome Western Areas Joint Venture (South Deep), South Africa
}

At South Deep, mining currently takes place at a depth of between $2400 \mathrm{~m}$ and $2650 \mathrm{~m}$ below surface. The orebody comprises Witwatersrand conglomerates and varies from $1 \mathrm{~m}$ thick to $120 \mathrm{~m}$ thick and extends over several kilometres. The narrow tabular portion of the orebody (Ventersdorp Contact Reef) is mined using a conventional mini-longwall mining method. The same method is used to mine a tabular cut within the massive portion of the orebody in order to de-stress the remainder of the massive orebody above and below. A system of regional stabilising pillars, together with the placement of cemented cycloned classified tailings is utilised to minimise seismic energy emission. Mechanised mining methods are used to extract the remainder of the massive orebody, which has been de-stressed.

A mine-wide seismic system comprising 19 triaxial sensors has been installed and is being used to monitor the levels of seismicity. The system is sensitive and records seismic events less than ML 1.0 throughout the active mining area. At present, relatively few large seismic events occur and seismic damage is infrequent in comparison to neighbouring mines at a similar depth. Only one rockburst has been induced directly by the mechanised massive mining, due to the very effective de-stressing method. However, minor damage has occurred due to large events on geological structures and regional pillars, where these have been induced by the de-stress tabular mining. A denser array of seismic sensors is to be installed within the mechanised massive mining areas to monitor the extraction of the temporary pillars and the stability of the regional pillars.

In this paper, the level of seismic activity throughout the mine will be quantified. The effectiveness of the measures to minimise seismic energy emissions will be assessed using numerical modelling techniques and evaluated using the seismic data obtained.

\section{INTRODUCTION}

South Deep Mine is situated approximately $45 \mathrm{~km}$ west of Johannesburg and $20 \mathrm{~km}$ south of Randfontein in the West Witwatersrand mining region. The mining authorisation area covers 3,563 hectares and extends for $9.5 \mathrm{~km}$ North-South and $4.5 \mathrm{~km}$ East-West at its widest points. Extensive mining has been carried out in the upper levels (North) between 1500 $\mathrm{m}$ to $2400 \mathrm{~m}$ below surface. Current mining takes place in the southern part of the lease area in an area of approximately $2 \mathrm{~km} \times 2 \mathrm{~km}$ at a depth of $2400 \mathrm{~m}$ to $2650 \mathrm{~m}$ below surface.

The mine is bounded by Kloof, Libanon, Venterspost and Randfontein Estates Gold Mines at its western and northern extremities respectively. Fig. 1 shows the position of the mine relative to existing infrastructure and neighbouring mines.

\subsection{Orebody}

The South Deep orebody lies within the Central Rand Group of the Witwatersrand Supergroup and is overlain by the Ventersdorp Lavas. The Ventersdorp Contact Reef (VCR) and Upper Elsburg reefs are of economic importance. The Upper Elsburg reefs subcrop against the base of the VCR (Fig. 2), which is a major stratigraphic unconformity. Towards the east the orebody diverges and thickens up to $120 \mathrm{~m}$ at the eastern extremity of the mine boundary, with an increasing percentage of unpay quartzite middlings occurring. This wedge is divided into two members, the Elsburg Massives (Modderfontein member) and the Elsburg Individuals (Waterpan member). The Elsburg Massives are sub divided into three units, the MA, MI (Intermediate) and MB, while the Elsburg Individuals comprise the EA, EB and EC units, of which only the EC horizon is exploited. An argillaceous quartzite (ED horizon) forms a sterile middling between the

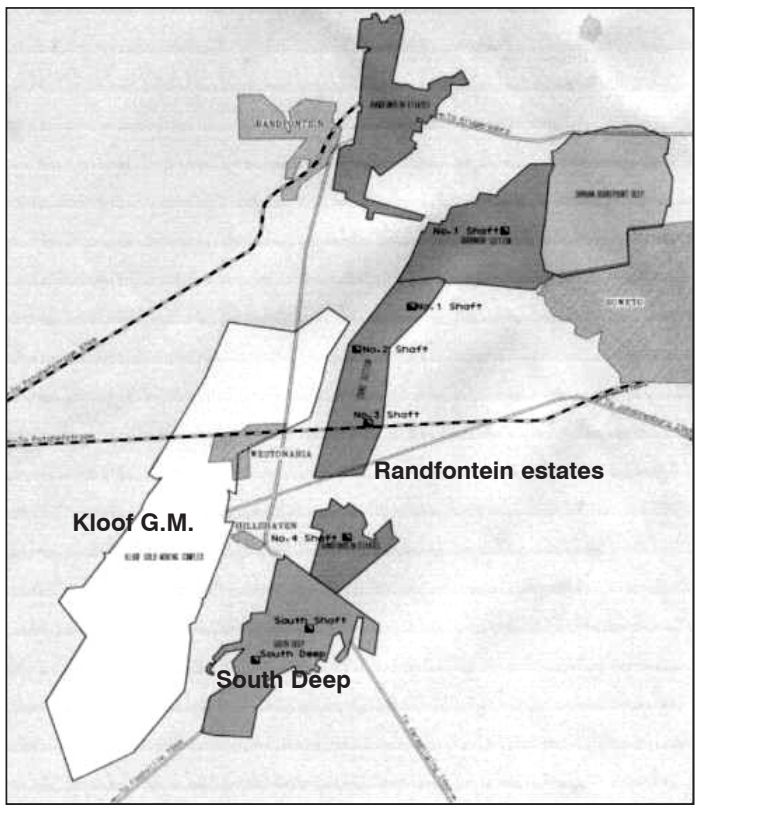

FIG. 1 Location of South Deep

Elsburg Massives and the Elsburg Individuals. The Upper Elsburg reefs coalesce westwards towards the subcrop, or shoreline as it is referred to locally. Individual units are difficult to differentiate near the subcrop and the package is then commonly referred to as the Shoreline Composite (SLC), from a package thickness of $10 \mathrm{~m}$. West of the subcrop, the 
VCR is the only well developed horizon, a narrow tabular reef up to $2.5 \mathrm{~m}$ thick. The economic viability of the VCR reduces east of the subcrop.

\subsection{Description of the Mining Areas and Mining Methods}

A suite of different mining methods have been employed at South Deep in order to optimise the ore resource, whilst striving to ensure that these are the safest and most cost effective mining methods available. Work in this regard is an ongoing process, as the confidence and level of knowledge and detail in the orebody is increased, and opportunities present themselves.

The VCR on the western side of the subcrop 90-95 (6W-9W) (Fig. 3) is mined as a conventional mining stope in an overhand mining configuration, making use of suitably designed dip and strike stabilising pillars together with a cemented cycloned classified tailings (CCT) backfill (specific gravity $=1.70$ ), up to stoping widths of $2.5 \mathrm{~m}$. Initial mining of the $9 \mathrm{~W}$ VCR provided early extraction of the new South Deep shaft pillar. A very stiff backfill product comprising crushed waste mixed with cemented CCT was used to minimise deformation in the new shaft system.

The de-stressing cut which is a functional requirement for the subsequent mechanised massive mining operations success, is carried out on the eastern side of the subcrop (85-90 (1W-3AW) and 90-95 (1W-3W)) (Fig. 3) This is mined as a conventional mining stope in an overhand mining configuration, making use of suitably designed dip stabilising pillars together with a cemented CCT backfill (specific gravity $=1.70$ ), up to stoping widths of $1.8 \mathrm{~m}$.

The primary purpose of the backfill in the VCR and the de-stress cut mining provides security, by minimising the Energy Release Rates (ERR) in line with the industry

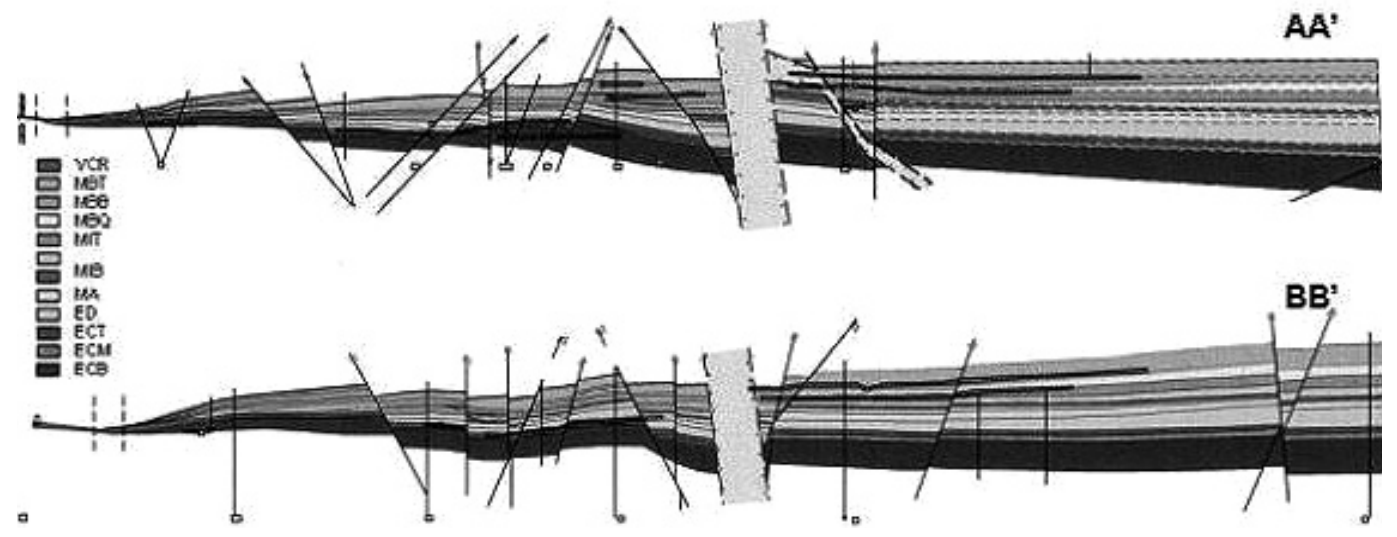

FIG. 2 Generalised East-West section showing the stratigraphy of the orebody

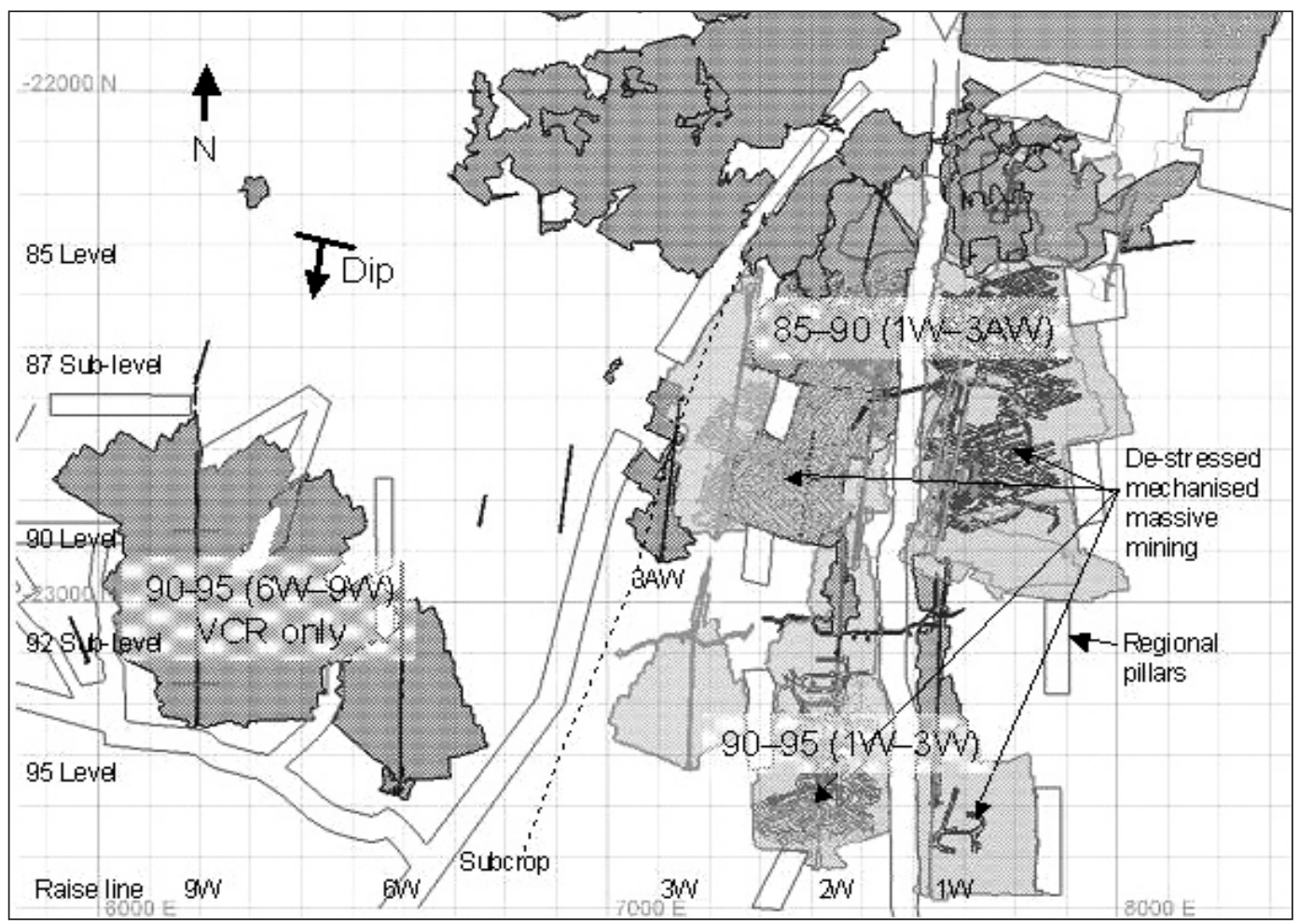

FIG. 3 Mine plan of South Deep current mining areas 
accepted values and also increases the extraction ratio, by reducing the regional pillar design requirements (also improves ventilation to the face). In reality, this also needs to be offset against the mining cycle efficiency when looking at mining with backfill as opposed to mining without backfill. The support system employed in the VCR and the conventional de-stress cut mining stopes is indicated in Figure 4, which employs a system of pre-stressed timber elongates together with headboards.

The mechanised massive mining operations is carried out using a drift and fill operation as well as a drift and fill with benching operation making use of a cemented CCT backfill (specific gravity $=1.80$ ) together with a suitably designed pillar extraction sequence, which needs to be rigidly adhered to, (Joughin and Pethö, 2004).

The primary function of the free-standing backfill in the mechanised massive mining operation provides confinement to the secondary pillars, which are extracted later and minimises the occurrence of large backbreaks. Proper compliance to tightfilling in the mechanised massive mining projects must be maintained throughout. Proper planning needs to be done upfront to ensure that the backfill operation functions as described above and that the filling operation does not provide further problems to the mining cycles.

\subsection{Production}

Underground production from the various mining areas, from January to August 2004, can be seen in Fig. 5, which varies between 100,000 tonnes per month and 150,000 tonnes per month, except for April (Easter break). This is made up of mechanised massive mining; contributing from 60,000 tonnes per month to just over 90,000 tonnes per month and conventional mining contributing from 40,000 tonnes per month to just over 60,000 tonnes per month.

\subsection{Accident Statistics}

Looking over the mine rock related fatalities for the period 1992 until August 2004 (Fig. 6), it can be seen that the rockfall related fatalities have contributed to just under $53 \%$ of all the recorded fatalities, whilst the rockburst and strainburst fatalities have contributed just under $11 \%$ of all the recorded fatalities. Taken together these account for around $64 \%$ of all the recorded fatalities. Viewed on a macro scale, however, the overall trend for fatalities is positive, decreasing over this period under review.

Another way of viewing the overall mine safety statistics can be obtained when comparing the Lost Time Injuries (LTI) Rates and Total Injury Rates; once again an overall improvement has been achieved since 1999, with a slight upturn noted in the recent period (Fig. 7). The Australian Mining Lost Time Injury Frequency Rate (LTIFR) Average has also been included for comparison, which is derived by taking the Lost Time Injury Rate and dividing this number by 200,000 hours.

The rockfall and rockburst related incidents recorded for January 2004 until August 2004 in terms of First Aid Injuries (FAI), Medical Aid Injuries (MAI), LTI and Fatalities are shown in (Fig. 8). Once again, the rockfall incidents dominate, with a total of 103 rockfall incidents, of which 14 were LTI and one was a fatality, versus five minor (MAI) rockburst related incidents occurring during this period under review (Fig. 8).

It is thus apparent that during the last 12 years, rockburst related incidents and fatal injuries have not been a common occurrence on South Deep. Fig. 9 shows that South Deep (reported as Placer Dome WAGM) has one of the lowest fall of ground casualty rates for deep level gold producing mines in the area for the past two years.

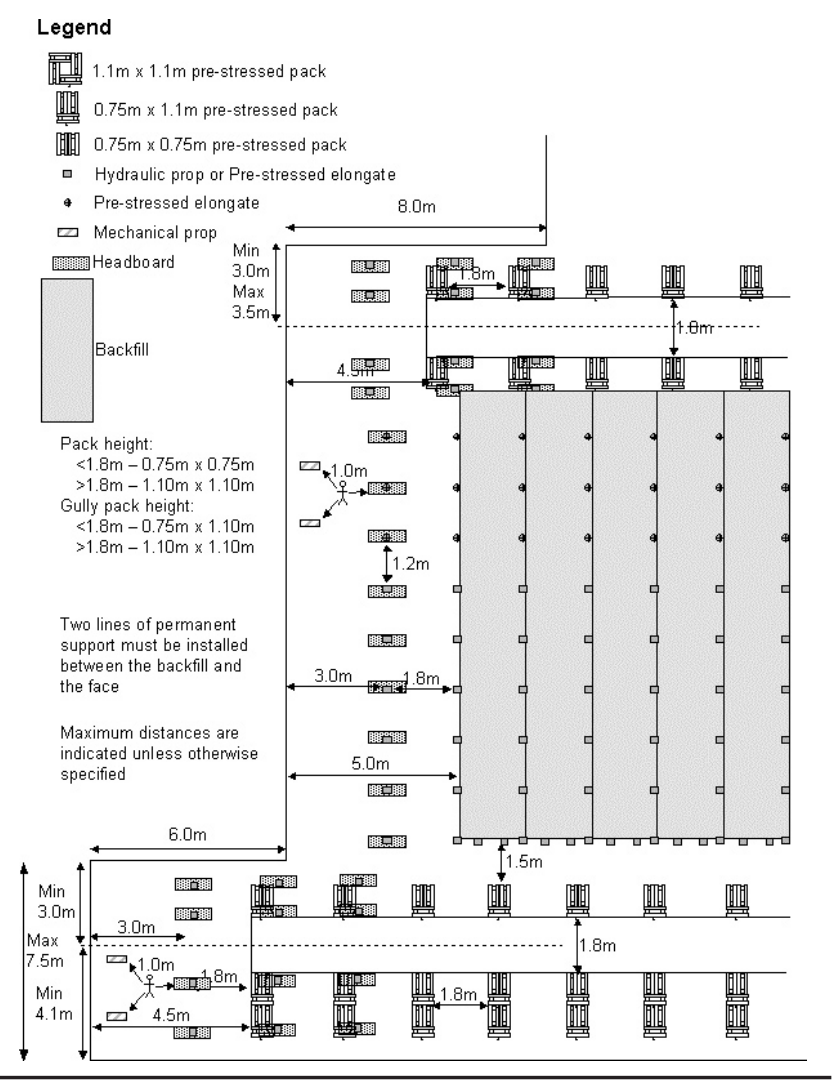

FIG. 4 Support standard in the conventional tabular stopes

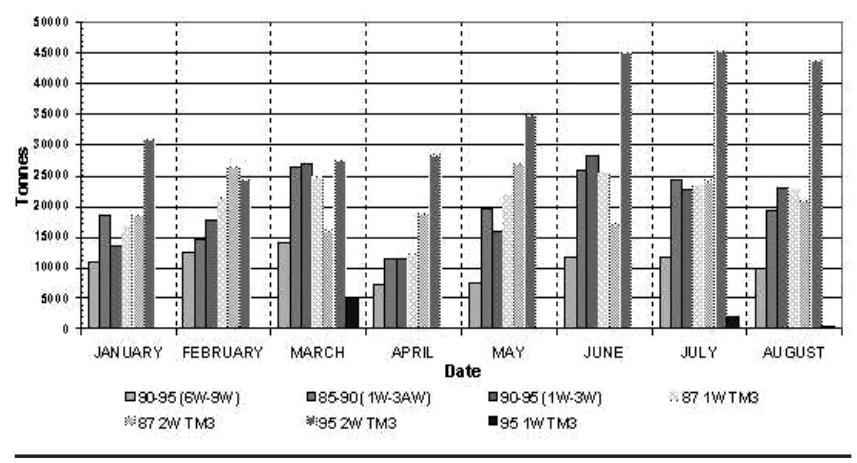

FIG. 5 Underground production statistics from 01/2004 to 08/2004

\subsection{Seismic System}

A PSS seismic system was installed in 1995 to monitor seismicity associated with the early extraction of the shaft pillar in the 90-95 9W VCR. It was installed on two working levels comprising 5 geophones and provided good data in this area until it was de-commissioned in 1998. This system was replaced with an ISSi seismic system, covering the entire current mining area indicated on Fig. 3 and the first data was recorded in April 2002. The seismic network comprises 19 triaxial geophones. Seismic waveforms are digitally recorded using Multiple Seismometers (MS) situated near the sensor (between $10 \mathrm{~m}$ and $300 \mathrm{~m}$ ).

Initially data was transferred to the cental site on surface utilising the mine's leaky feeder network on the three working levels and old telephone cables in South shaft. This data communication system proved extremely unreliable and data was frequently lost. Amplifiers within the leaky feeder network were frequently down, which did not affect voice communication, but caused significant data loss on the seismic system. The radios also proved unreliable in 


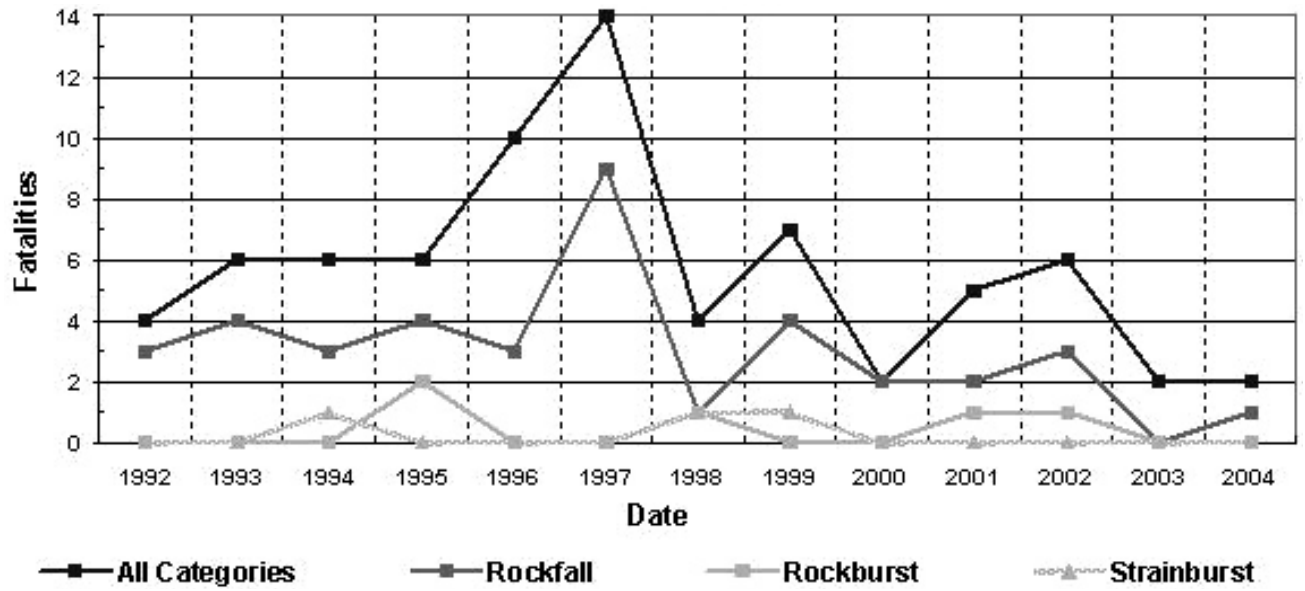

FIG. 6 Rock related fatalities from 1992 until August 2004

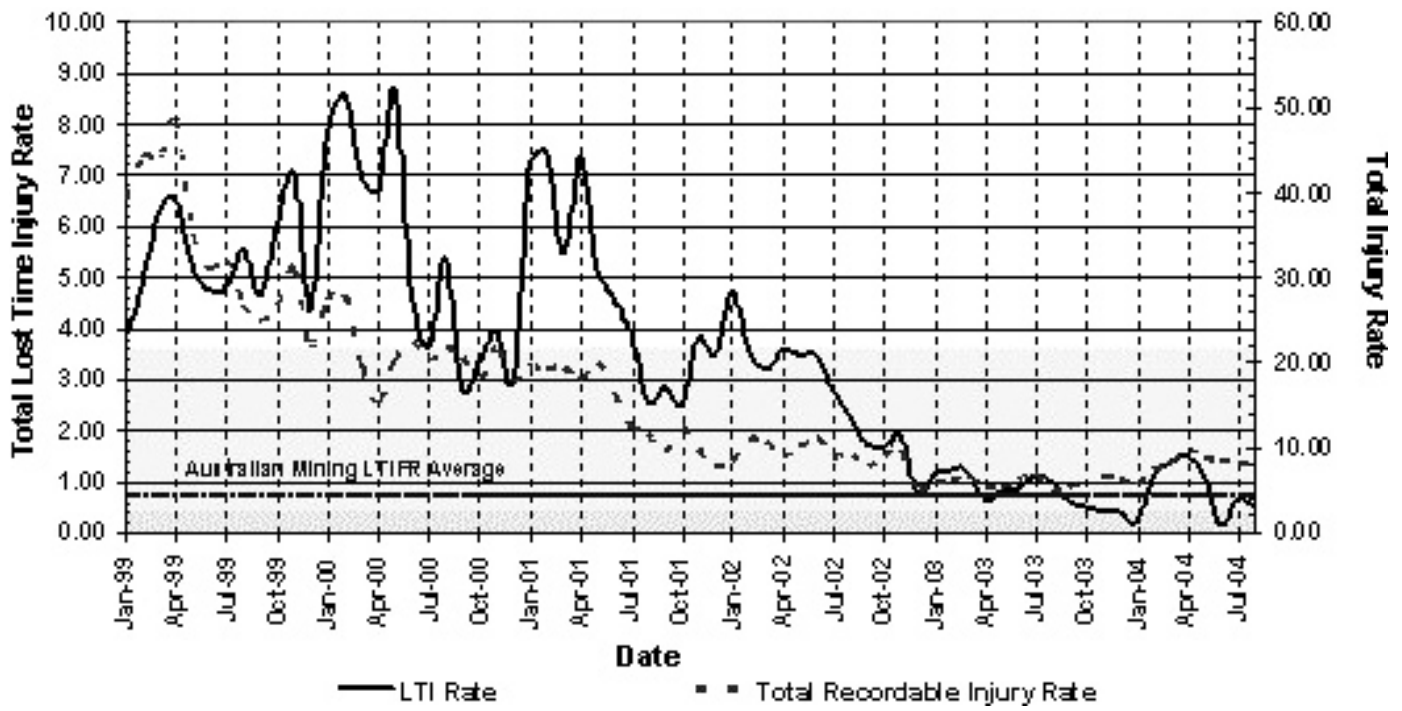

FIG. 7 LTI and total injury rates from 1999 until August 2004

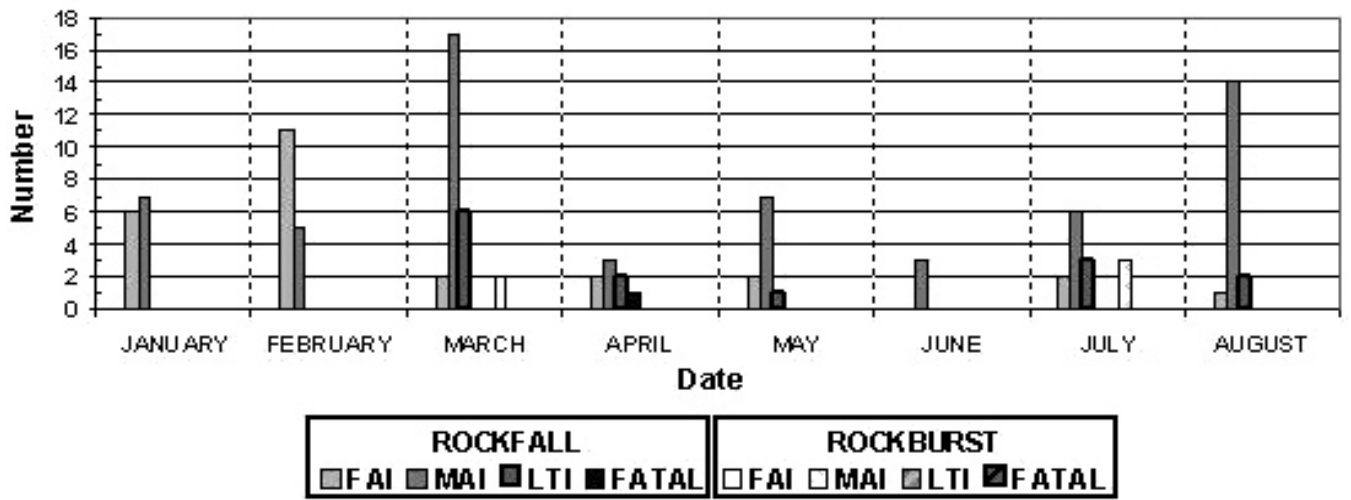

FIG. 8 Rockfall and rockburst related incidents from January 2004 until August 2004 


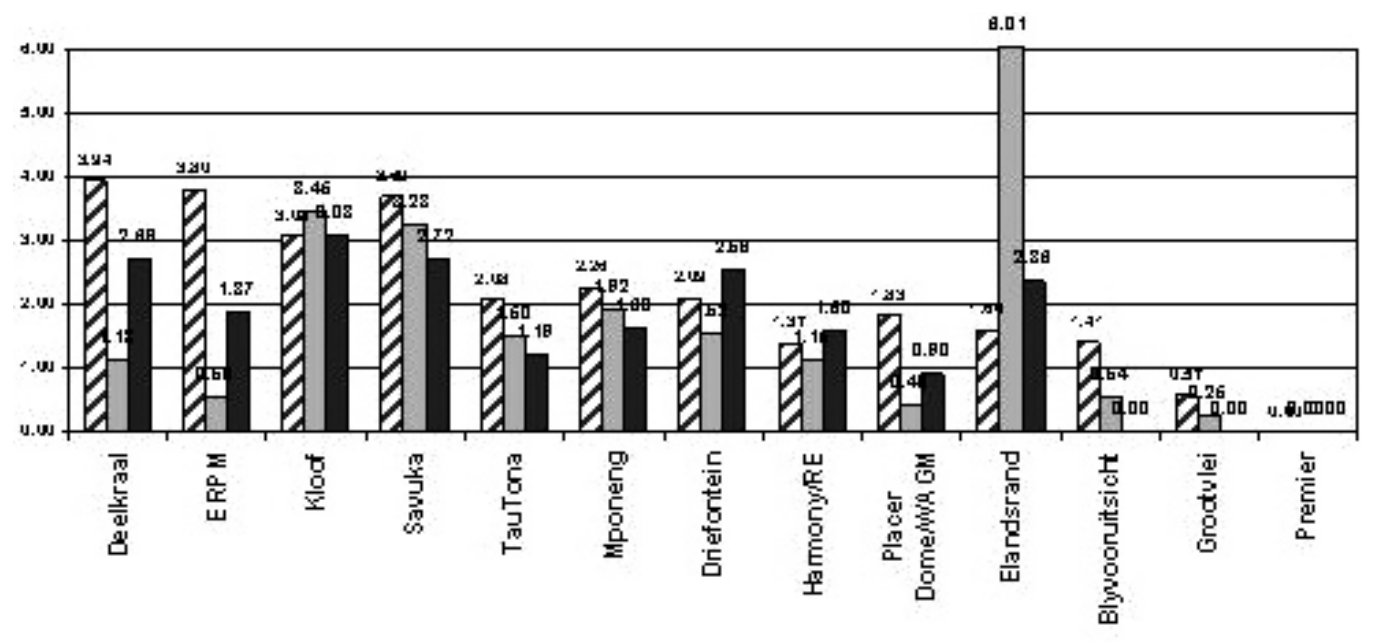

שJar-Dec 2002

ㅁ.Jan-Dec 2003

DJan-Dec 2004

FIG. 9 Gauteng region fall of ground casualty rate per million man hours worked (August 2004: Mine Health and Safety newsletter - Department Of Minerals And Energy, Republic Of South Africa)

the underground environment. Not only were individual sensors frequently down, but also the synchronisation of the MS boxes was affected preventing reliable recognition of real seismic events. Also, the old copper cable in the shaft would often lose continuity rendering the entire seismic network inoperable.

In December 2002, a Fibre Optic network was installed in South shaft and the seismic system was reconfigured to utilise it. Following this, data communication within the shaft was extremely reliable, but significant problems were still being experienced with the leaky feeder system, despite intensive maintenance and minor modifications. It was therefore motivated to install a dedicated copper cable communication system for horizontal tunnels, which was completed in October 2003. Data communication is now extremely reliable and sensor downtime is very low, averaging less than 3\%. After switching over the baud rate also increased from $4.8 \mathrm{kbaud}$ to $38.2 \mathrm{kbaud}$, and all seismic waveforms are received within 20 seconds of occurrence of a seismic event. The data set can be considered complete and accurate from October 2003 onwards.

The seismic system was designed to be sensitive enough to record seismic events of Local Magnitude $\left(\mathrm{M}_{\mathrm{L}}\right)-1.0$ and have a location accuracy of between $15 \mathrm{~m}$ and $25 \mathrm{~m}$. In practice, the seismic system records many seismic events of less than $M_{L}-1.0$, in most areas of the mine, but in some areas, the sensitivity is not as good as anticipated, due to attenuation of the wave energy through the mining excavations.

The velocities have been calibrated through large production blasts, with $5 \mathrm{~m}$ to $13 \mathrm{~m}$ long, $61 \mathrm{~mm}$ diameter vertical blastholes, with between $11 \mathrm{~kg}$ and $37 \mathrm{~kg}$ of explosives. Theses are set off with a $200 \mathrm{~ms}$ delay and the P and $S$ wave arrivals of the first shot can normally be easily detected. Typically these blast events range between $M_{L} 0.6$ and 0.9 . The following velocities were calculated and are being utilised:
P wave:
$5900 \mathrm{~m} / \mathrm{s}$
S wave
$3600 \mathrm{~m} / \mathrm{s}$

Subsequent production blasts have been located to within $20 \mathrm{~m}$ (in 3D) of the breaking point, using these velocities. However, poor locations do occur when there is no direct path between the source and one or two of the sensors, due to the large mining voids. The resultant ray paths can be up to $30 \%$ longer and this forces the calculated location to be up to $200 \mathrm{~m}$ deeper or shallower than the true location. The East
West error is usually unaffected, but a North South error of up to $50 \mathrm{~m}$ normally occurs. To improve on this situation, a database of production blasts is now being maintained and those that are well located will be used for relative locations.

TABLE 1 Performance characteristics of the seismic system

\begin{tabular}{ll}
\hline Performance characteristic & Value \\
\hline Location accuracy $(\mathrm{m})$ & 15 to 25 \\
Station density (stations within $1 \mathrm{~km}$ of source) & 6 \\
Sensitivity (minimum magnitude) & -1.0 \\
Seismic event rate (events/day) & \pm 200 \\
Sensor type & $4.5 \mathrm{~Hz}$ geophones \\
Frequency range $(\mathrm{Hz})$ & 2 to 400 \\
Dynamic range $(\mathrm{dB})$ & 132 \\
Communication rate $(\mathrm{b} / \mathrm{s})$ & 38400 \\
\hline
\end{tabular}

It is planned to install dense seismic networks within the mine seismic network to monitor microseismicity within the mechanised massive mining projects to monitor the stability of temporary pillars and the regional pillars. Three semimobile mini-networks, comprising a Quake Seismometer (QS), one triaxial $30 \mathrm{~Hz}$ geophone and three uniaxial $30 \mathrm{~Hz}$ geophones will each monitor a $200 \mathrm{~m} \times 100 \mathrm{~m}$ area. These will be integrated with the mine seismic network and are scheduled to be completed by the end of 2004 .

\section{SEISMIC ACTIVITY AT SOUTH DEEP}

\subsection{Seismic Hazard Analysis}

The current seismic network has been recording data since April 2002, but consistent reliable data has only been available since October 2003. Therefore the statistical analysis is based on the period 01/01/2004 to 31/08/2004. A brief analysis utilising all available data is also included.

\subsubsection{Method of analysis}

Gutenberg-Richter (1944) frequency magnitude distributions were used to determine the $b$ value and maximum expected magnitude $\left(\mathrm{M}_{\max }\right)$ which is compared with the maximum observed seismic event $\left(\mathrm{M}_{\mathrm{obs}}\right)$.

$$
\begin{gathered}
\log _{10} \mathrm{~N}\left(\mathrm{M}_{\mathrm{L}}\right)=\mathrm{a}-\mathrm{bM} \mathrm{L}_{\mathrm{L}} \\
M_{\text {max }}=\log _{10} N\left(\geq M_{\text {min }}\right) / b+M_{\text {min }}
\end{gathered}
$$


The curve is fitted utilising the seismic analysis package JDi. Richardson and Jordan (2001) showed that two distinct classes of seismic events occur; type A, which are "fracture dominated" ruptures and type B, which are "frictiondominated" ruptures. Where both classes occur within one data set, only the type B seismic events were considered as these are considered to be the most hazardous. JDi allows a minimum magnitude to be selected and the curve is fitted through all seismic events above this magnitude (Fig. 10).

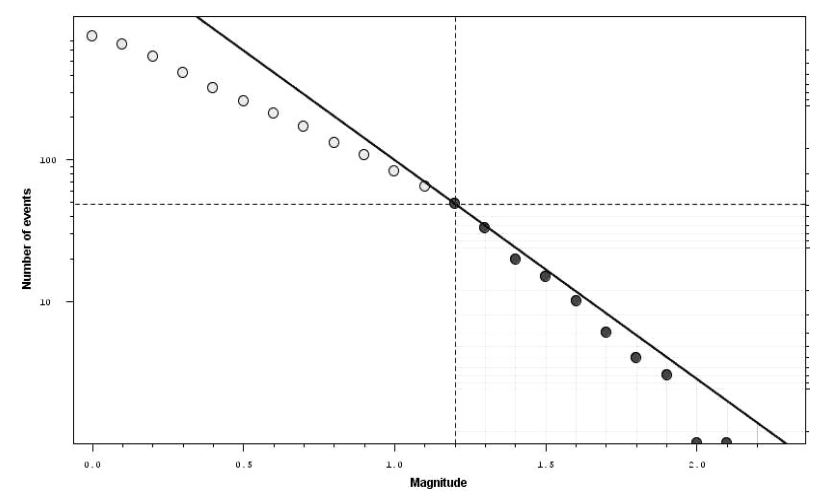

FIG. 10 Gutenberg-Richter frequency-magnitude distribution for South Deep data recorded between 01/01/2004 and 01/08/2004. (Note that the line is fitted through the type B seismic events, which represent the greater hazard)

The Seismic Hazard Scale (SHS) proposed by Hudyma and Potvin (2004) is essentially $\mathrm{M}_{\max }$ determined by assuming $\mathrm{b}$ $=1.0$ :

$$
M_{\max } \approx S H S \approx \log _{10} N\left(>M_{L}\right)+M_{L}
$$

SHS was calculated for $\mathrm{M}_{\mathrm{L}} 0.0 ; 0.5 ; 1.0 ; 1.5$ and 2.0 and then the average and maximum of these was determined. The results are compared with those obtained for Australian mines (Table 2).

Several South African gold mines would rank as very high to extreme hazard according to Table 2. Mines in Klerksdorp and Welkom regions have $M_{\text {max }}$ values on regional structures of greater than 4.0 (Ebrahim-Trollope, 2001 and 2004). Mines in the Carltonville area have individual mining areas with short term hazard values (200 days) $\mathrm{M}_{\max }>3.0$, with the highest being 3.7 (van Aswegen, 2004 and 2005). It should be noted that mining on these mines is far more extensive than at South Deep and good quality seismic data has been recorded for 10 years or more. The stress changes on regional structures are far greater than at South Deep. The calculation of $M_{L}$ also varies, so comparisons can only be made in the broadest terms. However, for the Carltonville area, the $M_{L}$ calculations are the same.

The ratio of Energy(E) to Moment(M) provides an indication of the stress level or stiffness. Mendecki and van Aswegen (2001) propose using the parameter $\mathrm{K}_{\mathrm{AS}}$ :

$$
K_{A S}(d, c)=G\left(E_{2}-E_{1}\right) /\left(M_{2}-M_{1}\right)
$$

Where $G$ is the Shear Modulus (30GPa) and $E_{2}$ and $E_{1}$ are the typical values of $E$ for two values of $M\left(M_{2}=1 E 13, M_{1}=\right.$ $1 \mathrm{E9})$, determined using the E-M relation:

$$
E=c+d \log _{10} M
$$

Where c and $\mathrm{d}$ are empirically derived constants. These values were determined using JDi. Naicker (2003) showed that $\mathrm{K}_{\mathrm{AS}}$ is a useful parameter for assessing seismic hazard in his evaluation of the relationship between mine seismicity and depth of mining. The seismic hazard for individual mining areas can be compared by plotting $\mathrm{M}_{\max }$ versus $\mathrm{K}_{\mathrm{AS}}$ (van Aswegen, 2001, 2003a, 2003b and 2005).

TABLE 2 SHS and the equivalent relative seismic hazard. The SHS determined for 11 mines and 16 mining blocks are grouped into these categories for comparison (from Hudyma and Potvin, 2004)

\begin{tabular}{llll}
\hline $\mathbf{S H S} \approx \mathbf{M}_{\max }$ & $\begin{array}{l}\text { Relative Seismic } \\
\text { Hazard }\end{array}$ & $\begin{array}{l}\text { Number of } \\
\text { mines }\end{array}$ & $\begin{array}{l}\text { Number of } \\
\text { mining blocks }\end{array}$ \\
\hline 0 & Low & 0 & 0 \\
0.5 & & 0 & 1 \\
1.0 & Moderate & 1 & 2 \\
1.5 & & 1 & 4 \\
2.0 & High & 3 & 4 \\
2.5 & & 5 & 5 \\
3.0 & Very High & 1 & 0 \\
3.5 & & 0 & 0 \\
4.0 & Extreme & 0 & 0 \\
\hline
\end{tabular}

Seismic events that occur during and after blasting time do not pose a risk, since people are not exposed to these. The re-entry periods allow seismic activity rates to drop off. The proportion of on shift seismic events was determined to evaluate the exposure of people to potentially damaging seismic events.

Seismic moments can be compared with the volume of elastic convergence $\left(\mathrm{V}_{\mathrm{e}}\right)(\mathrm{McGarr}, 1976)$ :

$$
\Sigma M=\gamma G V_{e}
$$

The proportional constant $\gamma$ has been found to vary between 0.03 and 1.0 and there is some evidence that it is a function of the geotechnical area being mined (Mendecki and van Aswegen, 2001). Elastic numerical modelling was carried out using Map3D to determine $\mathrm{V}_{\mathrm{e}}$. The mined out tabular stopes were represented as displacement discontinuity elements and backfill was modelled using the backfill-hyperbolic criterion. All tabular mining until December 2003 was modelled in the first step and tabular mining until June 2004 was modelled in the second step. The difference in $\mathrm{V}_{\mathrm{e}}$ was used to determine $\gamma$ during this period.

\subsubsection{Results}

The results are listed in Table 3 . The largest seismic event recorded by the seismic network is $M_{L} 2.8$, with a corresponding $\mathrm{M}_{\text {max }}=3.0$. Between January 2004 and August 2004, the largest seismic event recorded reduced to $M_{L} 2.1$, with a corresponding $M_{\max }=2.3$. The $90-95(6 \mathrm{~W}-9 \mathrm{~W})$ has the lowest $\mathrm{M}_{\max }=1.4$.

The relatively high $\mathrm{b}$ values $(\geq 1.0)$ indicate that the loading system is relatively stiff. The $90-95(1 \mathrm{~W}-3 \mathrm{~W})$ has the highest b value, which could be related to the relatively small stope spans.

The SHS does not take the high $\mathrm{b}$ values into account and therefore represents a more conservative estimate of seismic hazard.

The $K_{A S}$ is highest for the $90-95(6 \mathrm{~W}-9 \mathrm{~W})$, which could be due to a high proportion of type A seismic events.

While the bulk of the seismic events occur during blasting time, $40 \%$ of the potentially damaging seismic events occur on shift. In the $85-90(1 \mathrm{~W}-3 \mathrm{~W})$ area, half of the potentially damaging seismic events occur on shift. 
TABLE 3 Statistical information for the mine based on data recorded. Mining areas are shown in Fig. 3

\begin{tabular}{|c|c|c|c|c|}
\hline & $\begin{array}{l}\text { South } \\
\text { Deep }\end{array}$ & $\begin{array}{l}90-95 \\
6-9 W\end{array}$ & $\begin{array}{l}85-90 \\
1-3 W\end{array}$ & $\begin{array}{l}90-95 \\
1-3 W\end{array}$ \\
\hline \multicolumn{5}{|c|}{ Seismic Hazard (18/04/2002 - 31/08/2004) } \\
\hline $\mathrm{M}_{\max }$ & 3.0 & 1.8 & 3.0 & 2.4 \\
\hline$M_{\text {obs }}$ & 2.8 & 1.8 & 2.8 & 2.1 \\
\hline$b$ & 1.2 & 1.3 & 1.0 & 1.5 \\
\hline \multicolumn{5}{|c|}{ Seismic Hazard (01/01/2004 - 31/08/2004) } \\
\hline $\mathrm{M}_{\max }$ & 2.3 & 1.4 & 2.3 & 2.1 \\
\hline$M_{o b s}$ & 2.1 & 1.4 & 2.1 & 1.9 \\
\hline$b$ & 1.6 & 1.0 & 1.2 & 1.6 \\
\hline $\mathrm{SHS}_{\text {ave }}$ & 2.8 & 1.4 & 2.4 & 2.5 \\
\hline $\mathrm{SHS}_{\max }$ & 2.9 & 1.5 & 2.5 & 2.6 \\
\hline $\mathrm{K}_{\mathrm{AS}}(\mathrm{Pa})$ & $5.5 \mathrm{E} 05$ & 3.3E06 & $5.5 \mathrm{E} 05$ & 5.2E05 \\
\hline \multicolumn{5}{|c|}{ Seismic events per month $(01 / 01 / 2004-31 / 08 / 2004)$} \\
\hline$M_{L}>2.0$ & 0.13 & 0 & 0.13 & 0 \\
\hline $\mathrm{M}_{\mathrm{L}}>1.5$ & 1.8 & 0 & 1.0 & 0.8 \\
\hline $\mathrm{M}_{\mathrm{L}}>1.0$ & 9 & 0.4 & 3.8 & 5.5 \\
\hline$M_{L}>0.5$ & 29 & 1.0 & 13.3 & 17.3 \\
\hline \multicolumn{5}{|c|}{ Seismic events on shift $(01 / 01 / 2004-31 / 08 / 2004)$} \\
\hline$\left(M_{L}>1.0\right)$ & $40 \%$ & 37 & $53 \%$ & $27 \%$ \\
\hline$\left(M_{L}>0.5\right)$ & $39 \%$ & 38 & $50 \%$ & $33 \%$ \\
\hline \multicolumn{5}{|c|}{$E, M$ and $V_{e}(01 / 01 / 2004-30 / 06 / 2004)$} \\
\hline$\Sigma \mathrm{E}(\mathrm{J})$ & 4.7Е07 & 4.9E06 & 3.0E07 & 1.4E07 \\
\hline$\Sigma \mathrm{M}(\mathrm{Nm})$ & 2.0E13 & 1.3E12 & 1.0E13 & 9.3E12 \\
\hline$V_{e}\left(m^{3}\right)$ & 8150 & 2198 & 2943 & 3055 \\
\hline$\Sigma \mathrm{M}_{\text {mod }}$ & $2.5 \mathrm{E} 14$ & $6.6 \mathrm{E} 13$ & 8.8E13 & $9.2 \mathrm{E} 13$ \\
\hline$\gamma$ & 0.08 & 0.02 & 0.12 & 0.10 \\
\hline
\end{tabular}

The $\Sigma \mathrm{M}$ is relatively low for the elastic convergence calculated, for the period analysed, and the $\gamma$ values range from 0.02 to 0.12 . The $90-95(6 \mathrm{~W}-9 \mathrm{~W})$ has a remarkably low $\gamma$ value of 0.02 .

\subsection{Occurrence of Large Seismic Events (ML>2.0)}

Fig. 11 shows all the large seismic events recorded at South Deep by the mine seismic system between April 2002 and August 2004. A few large seismic events occurred that were not recorded by the seismic system before October 2003.

A total of 9 large seismic events have been recorded, but only one large seismic event was recorded during 2004 $\left(M_{L}\right.$ 2.1), which occurred on the Gemsbokfontein no. 2 dyke. No large seismic events were recorded in the 90-95(6W-9W) and therefore Fig. 11 only shows the Eastern portion of the current mining area.

The Horst structure in the North West corner of Fig. 10 is the most seismically active structure on the mine. Several large events, some greater than $M_{L} 2.5$ have been recorded on this structure. The structure can be regarded as very high seismic hazard. Severe rockburst damage in the footwall development has been caused by two seismic events on this structure. Fig. 12 shows the rockburst damage that occurred in an overstressed crosscut with a $\mathrm{M}_{\mathrm{L}} 2.7$ seismic event. In the stope face area, negligible hangingwall damage has occurred with panels advancing towards this structure associated with these large seismic events. However, significant shakedown damage occurred in gullies and travelling ways due to

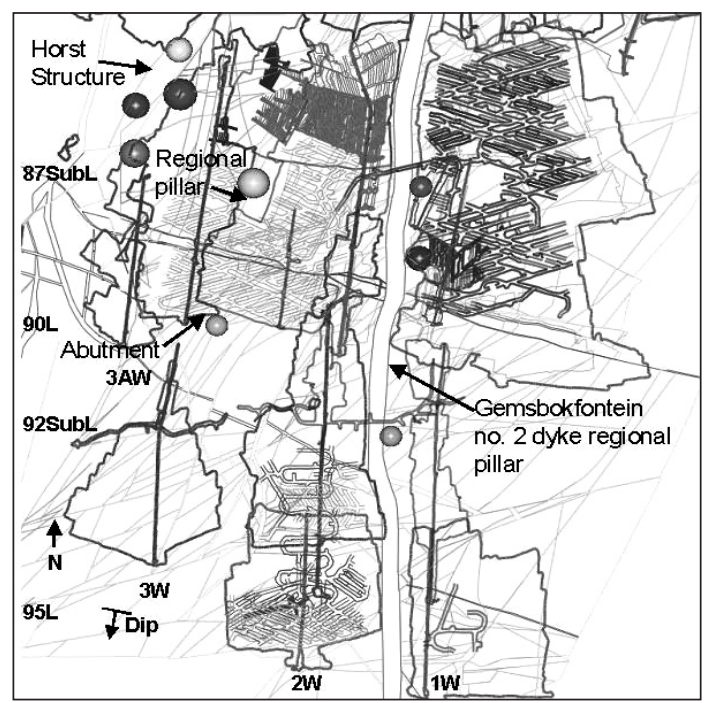

FIG. 11 Eastern portion of the current mining area showing large seismic events (ML>2.0) recorded between 01/04/2002 and 31/08/2004. No large seismic events (ML>2.0) have been recorded in the Western portion of the mine, where only the VCR is mined as a narrow tabular stope

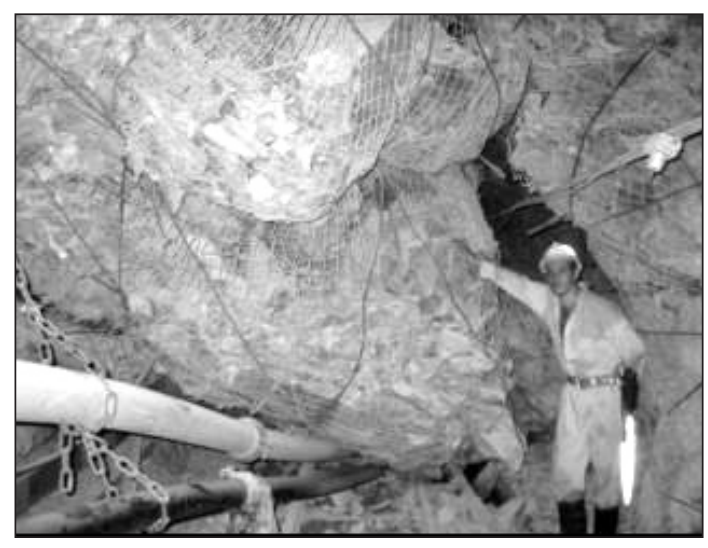

FIG. 12 Rockburst damage to crosscut caused by a ML 2.7 seismic event on the Horst Structure in March 2002

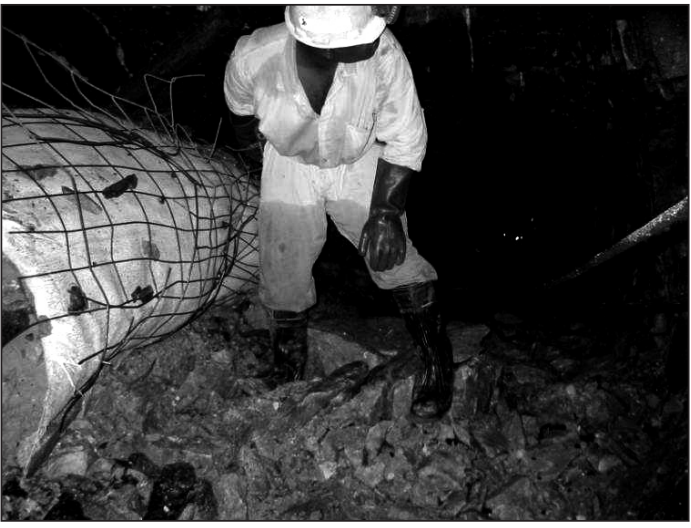

FIG. 13 Footwall lifting on the stope face, following a ML 2.3 seismic event (October 2003) on the Horst structure. The backfill had not consolidated and was compressed and spread out, displacing the elongate support. A gap of $30 \mathrm{~cm}$, between the backfill and the hangingwall, remained after the seismic event, indicating that the stope probably closed and opened, causing the footwall heave. Surprisingly, there were no rocks dislodged from the hangingwall 
deterioration of the blocky lava hangingwall with time. During one seismic event $\left(M_{L} 2.3\right)$, footwall lifting and stope closure occurred (Fig. 13). A conservative $25 \mathrm{~m}$ bracket pillar was designed and mining was completed during 2003. The $\mathrm{M}_{\max }$ for the whole mine dropped from 3.0 to 2.3 during 2004, mainly because this structure was not being activated.

The Gemsbokfontein no. 2 dyke forms a continuous dip regional pillar, with $12.5 \mathrm{~m}$ bracket pillars either side of the $25 \mathrm{~m}$ wide dyke. Several large events have occurred along the length of the dyke. The largest recorded event is $M_{L}$ 2.2. The seismic hazard for this structure is currently high risk, but is treated as very high risk as the $M_{\text {max }}$ could become 3.0 in the future. The dyke is approximately $1300 \mathrm{Ma}$ old and therefore much younger than the surrounding strata (2700Ma) and is stiff, strong and brittle. The contacts are welded with no faulting. A sidewall burst occurred in a highly stressed tunnel traversing the dyke (Fig. 14), which was associated with two seismic events $\left(M_{L} 2.5\right.$ and $\left.M_{L} 1.2\right)$ that probably occurred on the dyke. This tunnel has now been supported with yielding tendons, wire mesh and lacing and has effectively withstood subsequent large events on the dyke nearby. Minor damage has occurred in stopes due to seismic events located on the dyke.

A $M_{L} 2.6$ seismic event occurred on a regional pillar and a $M_{L} 2.1$ seismic event occurred on an abutment (Fig. 10). Both caused strainbursts and scattered rockfalls in large drifts located nearby. This type of damage occurs infrequently and cannot be anticipated.
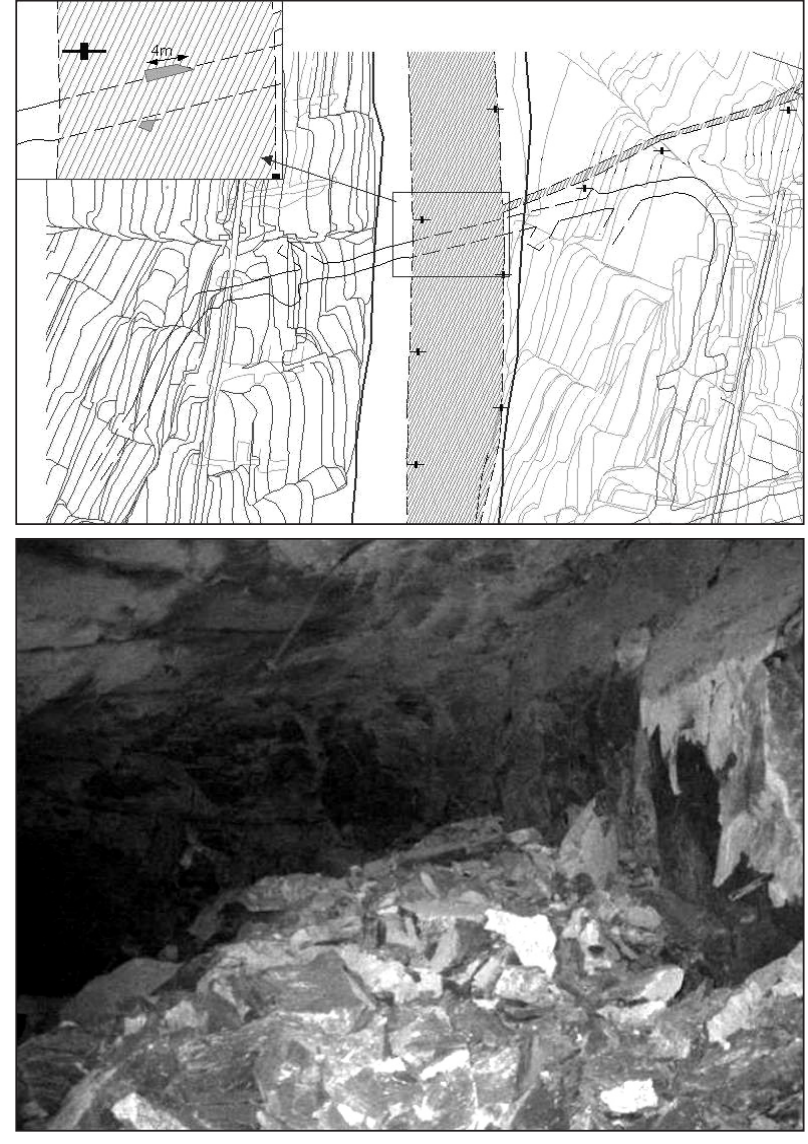

FIG. 14 Sidewall burst in a mechanised ramp development through the Gemsbokfontein no. 2 dyke and regional pillar. No seismic events were recorded due to a power failure, but the neighbouring mine recorded two seismic events (ML 2.5 and ML 1.2)

\subsection{Detailed Seismic Hazard Analysis}

The parameters $\mathrm{M}_{\max }$ and $\mathrm{K}_{\mathrm{AS}}$ were determined, from seismic data recorded between 01/01/2004 and 31/08/2004, for the mining areas indicated in Fig. 15, to assess the seismic hazard. The results are shown in Table 4 and Fig. 16.

In the 90-95(6W-9W) (West of subcrop) all the $M_{L}>1.0$ seismic events occurred on geological structures. Only three were recorded during 2004 and no associated damage was reported by mining personnel. The E-M relations could not be determined for each area, due to an insufficient spread of data and therefore an average $\mathrm{K}_{\mathrm{AS}}$ for $90-95(6 \mathrm{~W}-9 \mathrm{~W})$ was used. The $\mathrm{K}_{\mathrm{AS}}$ is high, probably since these are mostly type A seismic events (Richardson and Jordan, 2001), however, the hazard is low, since $M_{\max }$ is extremely low for each area (A1 to A4).
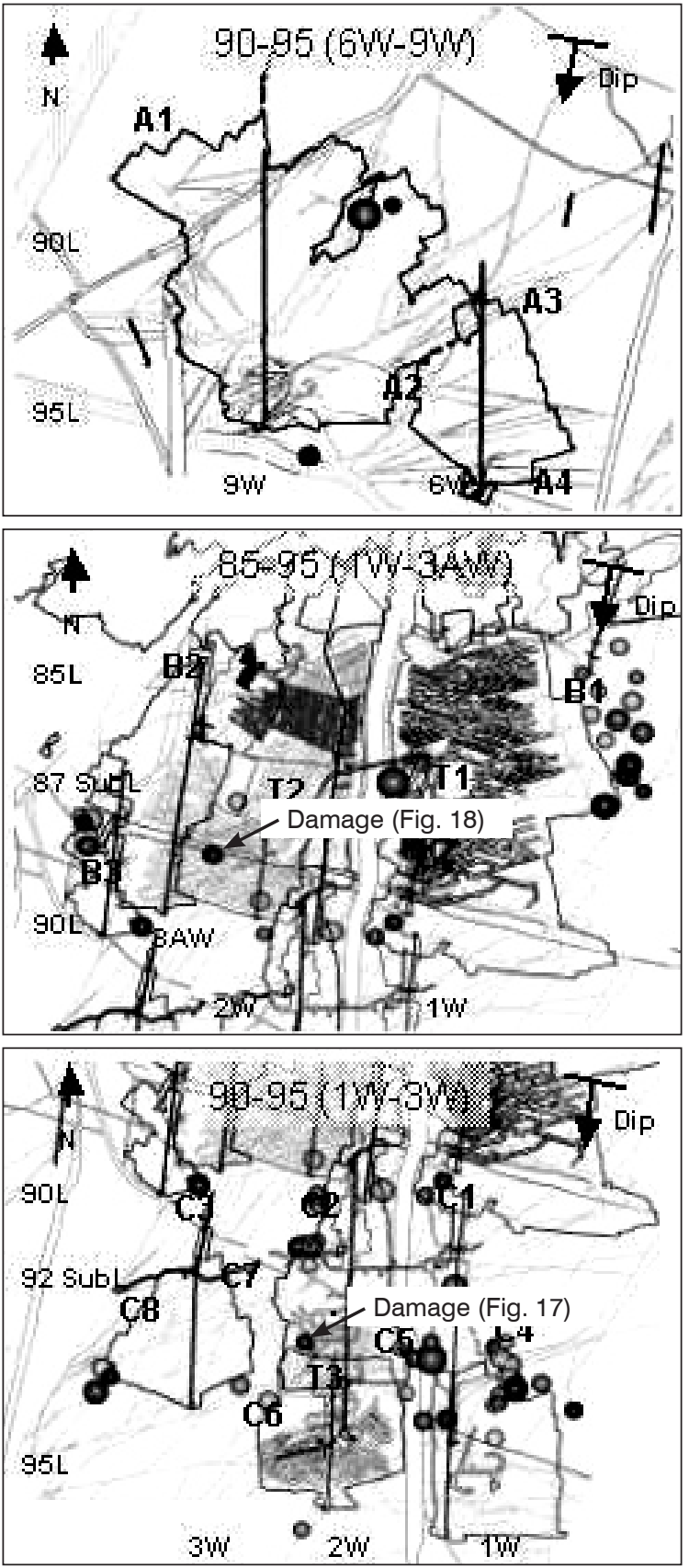

FIG. 15 Locations of seismic events $(M L>1.0)$ recorded between 01/01/2004 and 31/08/2004. The annotations represent mining areas in which hazard analyses were carried out (prefix A,B, C \& T) 
TABLE 4 Seismic hazard ranking according to $M_{\max }$

\begin{tabular}{lll}
\hline $\mathbf{M}_{\max }$ & $\begin{array}{l}\text { Relative Seismic } \\
\text { Hazard }\end{array}$ & Mining area \\
\hline 0 & Low & $\mathrm{A} 1, \mathrm{~A} 2$ \\
0.5 & & $\mathrm{~B} 2, \mathrm{C} 7, \mathrm{~T} 2, \mathrm{A3}, \mathrm{C} 3, \mathrm{~A} 4$ \\
1.0 & Moderate & $\mathrm{T} 1, \mathrm{~T} 3$ \\
1.5 & & $\mathrm{C} 6, \mathrm{C} 8, \mathrm{~B} 3, \mathrm{C} 1, \mathrm{C} 2, \mathrm{C} 5$ \\
2.0 & High & $\mathrm{B} 1, \mathrm{C} 4$ \\
\hline
\end{tabular}

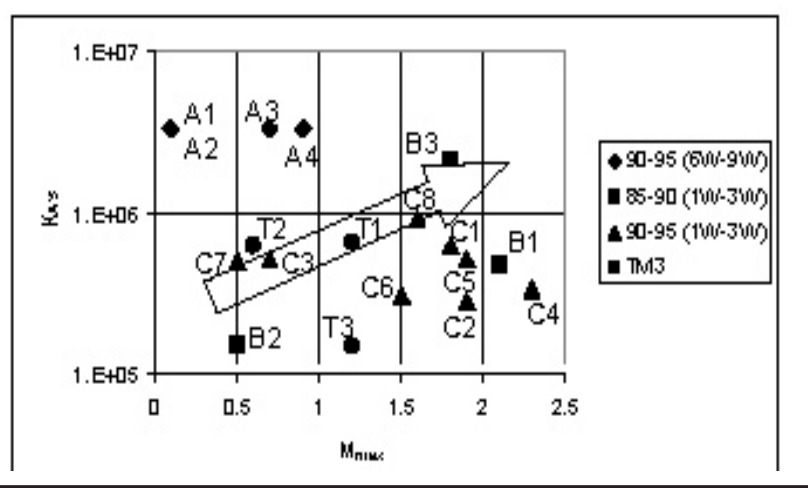

FIG. 16 Seismic hazard analyses of individual mining areas using the method proposed by van Aswegen (2001, 2003a, 2003b and 2005). The arrow represents increasing hazard. The names correspond with Figure 15

In the 85-90(1W-3AW) and 90-95(1W-3W) (East of subcrop) these seismic events generally locate immediately ahead of the mining faces. The most hazardous areas are B3, B1 and C4. The highest $M_{\max }$ is 2.3in C4, while B3 is hazardous due to a relatively high $\mathrm{K}_{\mathrm{AS}}$ and an $\mathrm{M}_{\max }$ of 1.8 associated with seismic events on the East-West striking Grizzley dykes.

Lost blasts due to seismic damage are practically non-existent. Occasional small seismic induced rockfalls occur, but injuries are infrequent (Section 0). One incident, on $28^{\text {th }}$ of November 2002, associated with a $M_{L} 1.0$ seismic event resulted in a major rockfall, closing up $15 \mathrm{~m}$ of the stope face and unfortunately causing a fatal accident (Fig. 17). The damage was partly due to shakedown and partly failure of rock slabs caused by low angle fracturing, which is described Nagel et al., 2004. This is the only known incident where extensive hangingwall damage has occurred. The support system was modified to include pre-stressed headboards on all elongate support units (Fig. 4) to improve areal coverage and reduce point loading. This change to the support system has reduced rockfalls and blast out of support units significantly, improving hangingwall conditions and reducing the number of rockfall injuries in stopes (Nagel, et al. 2004). Small facebursts (strainbursts) do occur and have caused minor injuries. Very few facebursts have occurred that affect more than a $2.0 \mathrm{~m}$ length of the stope face.

Two remnants are presently being mined (A2 and B2), both of which have ERR in excess of $60 \mathrm{MJ} / \mathrm{m}^{2}$. Both of these are extremely low hazard with $\mathrm{M}_{\max }$ of 0.2 and 0.4 respectively. They are nearing completion without ever having induced a potentially damaging seismic event. The mining rates are low in both cases, with only two panels being mined at a time.

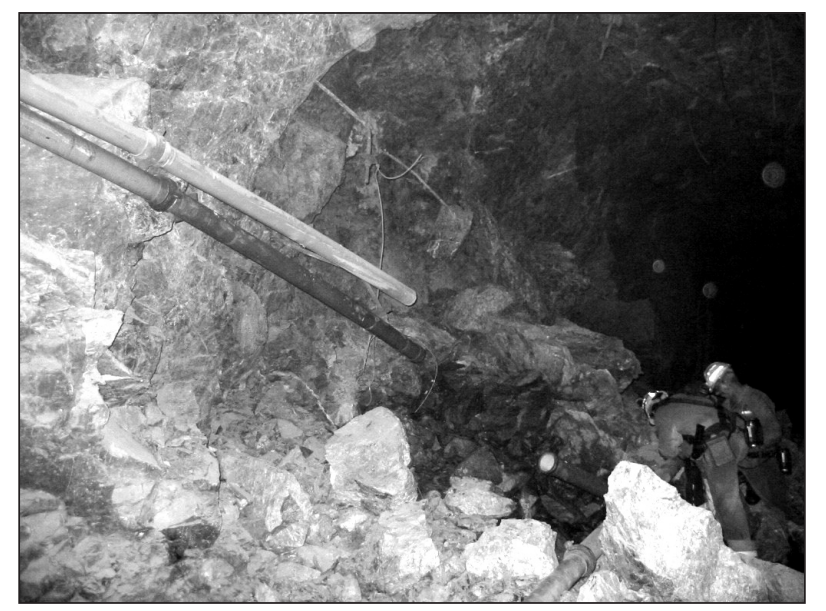

FIG. 17 Seismic damage associated with a ML 1.0 seismic event (November 2004. The damage was severe due to poor ground conditions associated with low angle fracturing (Nagel et al., 2004)

The de-stressed mechanised massive mining areas (T1, T2, and T3) are low hazard, with $\mathrm{M}_{\max }$ between 0.6 and 1.2. The seismic data used for the analysis excludes any seismic events located in nearby abutments, to investigate seismic events induced within the de-stressed area only. The vertical stress in the de-stressed areas is designed to be less than $40 \mathrm{MPa}$, but higher stresses will occur on the temporary pillars.

The de-stressing is very effective and good conditions are generally experienced in the mechanised massive mining areas (Joughin and Pethö, 2004). Two seismic events $M_{L}>1.0$ have been recorded in de-stressed areas, one of which caused rockburst damage (Fig. 18), in August 2004. The damage occurred along the East-West Grizzley dykes. This is the most severe damage that has been experienced in de-stressed excavations. The risk of injury is extremely low due to low exposure with mechanisation. Strainbursts occur in the T3 area quite frequently, since parts of the mining area are not fully de-stressed $(60 \mathrm{MPa})$ due to the stope geometry. This is being effectively managed by applying fibre reinforced wetcrete, where the strainbursting occurs. No injuries have occurred as a result of strainbursts or rockbursts in the mechanised massive mining areas.

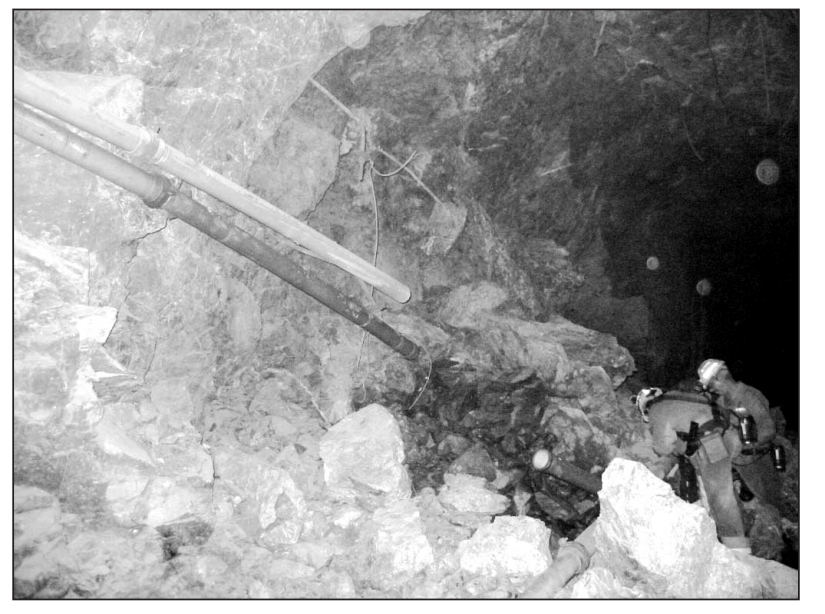

FIG. 18 Rockburst damage associated with a ML 1.3 seismic event in the 872 W TM3 de-stressed mechanised massive mining area (T1 in Figure 15) (August 2004) 


\section{CONCLUSIONS}

The relative seismic hazard at South Deep is comparable to some of the Australian mines investigated by Hudyma and Potvin (2004). The long term seismic hazard for the whole mine is very high $\left(\mathrm{M}_{\text {max }}=3.0\right)$, but this is mainly due to a single geological structure. In the short term (8 months data), the $\mathrm{M}_{\max }$ has dropped to 2.3 (high risk), with individual mining areas ranging from as low as 0.2 to 2.3 . This level of seismic hazard is lower than adjacent mines, which is probably due to a relatively small extent of mining (200 m x $2000 \mathrm{~m})$ at depth and the stress changes on the major geological structures are therefore relatively small. The use of good quality CCT backfill from the onset of deep level mining may also have significant effect. The seismic hazard in each of the mining areas has been determined so that appropriate strategies can be implemented.

The support system used at South Deep (Fig. 4), incorporating backfill, has been effective in minimising incidents of seismic damage. However, large seismic events $\left(M_{L}>2.0\right)$ have occurred on the Horst structure and the Gemsbokfontein no.2 dyke, which have caused significant damage. Any mining areas which could induce seismicity on these structures and could experience strong ground motion need to be treated as special areas. The mining layout and sequence, as well as the support need to be appropriately designed and managed.

De-stressed mechanised massive excavations and off reef tunnels that could experience strong ground motion associated with large seismic events on these structures and stabilising pillars need to have appropriate support designed and installed.

Remarkably, low levels of seismicity are being experienced in the West of the mine, where only the VCR is mined as narrow tabular stopes. This could be due to stiff crushed waste-cemented CCT backfill having been placed during the pre-extraction of the South Deep shaft pillar and subsequent cemented CCT backfill placement with the remainder of the mining. The reliable evidence presented, indicates that this area has a low seismic risk, which allows higher extraction ratios and more cost effective mining methods to be considered.

Remnant mining has been conducted with surprisingly low levels of seismicity, which could be due to the low mining rates. It is not certain whether this will be the case with future remnants, but continued seismic monitoring will be carried out to evaluate the risk. Reducing the mining rates will certainly reduce the risk, if this becomes excessive.

The de-stressing is extremely effective in reducing the hazards associated with both rockfalls and rockbursts.

\section{ACKNOWLEDGMENTS}

The management of South Deep Mine is gratefully acknowledged for permission to publish this paper. The advice provided by Gerrie van Aswegen of ISSi on the seismic hazard analysis is appreciated.

\section{REFERENCES}

Ebrahim-Trollope, R. (2001) Gutenberg-Richter relationship and mineinduced seismicity as observed at the African Rainbow Minerals mines-Klerksdorp. 5th Int Symposium on Rockburst and Seismicity in Mines (RASIM5) SAIMM Johannesburg.

Ebrahim-Trollope, R. (2004) Personal communication.

Gutenberg, B. and Richter, C.F. (1944) Frequency of earthquakes in California. Bull. Seismol. Soc. Am. 34: pp. 185-188.

Hudyma, M. and Potvin, Y. (2004) Seismic hazard in Western Australian mines. Journal of the South African Insitiute of Mining and Metallurgy, vol.104, no. 5.

Joughin, W.C. and Pethö, S.Z. (2004) Massive Mining at South Deep. 2nd International Seminar on Deep and High Stress mining, SAIMM, Johannesburg.

McGarr, A. (1976) Seismic moments and volume changes. Journal of Geophysics research, Volume 81, pp. 1487-1494.

Mendecki, A.J. and van Aswegen, G. (2001) Seismic monitoring in mines: selected terms and definitions. 5th Int Symposium on Rockburst and Seismicity in Mines (RASIM5) SAIMM Johannesburg.

Nagel, M., Pethö, S. Z. and Joughin, W.C. (2004) Low angle fracturing in de-stress stopes at South Deep Mine. 2nd International Seminar on Deep and High Stress mining, SAIMM, Johannesburg.

Naicker, N. (2003) The relationship between mine seismicity and depth of mining. MSc Dissertation, University of the Witwatersrand.

Richardson, E. and Jordan, T.H. (2001) Some properties of gold mine seismicity and implications for earthquakes. 5th Int Symposium on Rockburst and Seismicity in Mines (RASIM5) SAIMM Johannesburg.

van Aswegen, G. (2001) Analysis of the processes which lead to potentially damaging seismic events associated with geological structures and highly stressed areas in extensively mined areas and old mines. SIMRAC Final Report. GAP605, Department of Minerals and Energy, Pretoria (http:/ / www.simrac.co.za).

van Aswegen, G. (2003a) Seismic hazard assessment methods in mines. 10th International Conference on Rock Mechanics - ISRM2003, South African Institute of Mining and Metallurgy, Johannesburg, South Africa.

van Aswegen, G. (2003b) Towards Best Practice for Routine Seismic Hazard Assessment in Mines. 30th International Conference of Safety in Mines Research Institutes South African Institute of Mining and Metallurgy, Johannesburg, South Africa.

van Aswegen, G. (2004) Personal communication.

van Aswegen, G. (2005) Routine seismic hazard assessment in some South African Mines. Sixth International Symposium, in mines RASIM6, Australian Centre for Geomechanics, Perth. 